\title{
Analiza ryzyka a skuteczność realizacji gazowniczych projektów inwestycyjnych finansowanych przy udziale funduszy UE
}

\section{Risk analysis and the effectiveness of implementation of the gas investment project, financed with the participation of EU funds}

\author{
Szymon Kawa \\ Instytut Nafty i Gazu - Państwowy Instytut Badawczy
}

\begin{abstract}
STRESZCZENIE: Zarządzanie gazowniczym projektem inwestycyjnym jest procesem bardzo skomplikowanym zarówno od strony technicznej, jak i organizacyjnej. Techniczne i technologiczne przygotowanie i realizacja takiego projektu jest domeną inżynierów, którzy za pomocą dostępnych metod, narzędzi, materiałów i technologii są w stanie przygotować i przeprowadzić proces inwestycyjny. Na ten aspekt należy nałożyć całą organizację i zarządzanie procesem, czyli zorganizowanie i takie pokierowanie każdym z wymienionych elementów, aby projekt był realizowany zgodnie z założonym harmonogramem i nie wystąpiły kolizje zadań, ,,wąskie gardła", czy zbędne przestoje. Do tego potrzebne jest odpowiednie planowanie, a w jego ramach analiza ryzyka realizacji projektu inwestycyjnego. Artykuł ma na celu wykazanie istotności analizy ex ante (łac. z góry, przed wydarzeniem się czegoś) wszelkich przesłanek wystąpienia ryzyka i samego ryzyka w działalności przedsiębiorstwa realizującego projekt przy udziale funduszy europejskich dla powodzenia takiej inwestycji. Istotności o tyle dużej, że to jeszcze przed przystąpieniem do samego procesu inwestycyjnego konieczne jest przewidywanie i ustalanie mechanizmów zapobiegających zaistnieniu, czy niwelujących efekty materializacji ryzyka na każdym etapie procesu: planowania, przeglądu, wdrażania, monitorowania i ewaluacji. Sama świadomość kierownictwa na temat istnienia różnych zagrożeń w czasie pozwala na podejmowanie decyzji o podjęciu, bądź niepodejmowaniu inwestycji nawet przy dostępie do bezzwrotnego dofinansowania $\mathrm{z}$ funduszy UE. Analizę przeprowadzono na podstawie projektów inwestycyjnych w sektorze gazowniczym przedstawionych do dofinansowania ze środków Europejskiego Funduszu Rozwoju Regionalnego w ramach programu Infrastruktura i Środowisko 2014-2020.
\end{abstract}

Słowa kluczowe: inwestycje, ryzyko, fundusze UE, zarządzanie projektem.

ABSTRACT: Managing a gas investment project is a very complicated process, both from the technical and organizational side. The technical and technological preparation and implementation of such a project is the domain of engineers who use the available methods, tools and materials as well as technology and are able to prepare and carry out the investment process. This aspect should be complemented by the entire organization and management of the process, i.e. organizing and directing each of the listed elements so that the project is carried out in accordance with the assumed schedule and there are no collisions of tasks, bottlenecks or unnecessary downtime. To this end, appropriate planning is needed, and within it, a risk analysis of the investment project implementation. The aim of the article is to demonstrate the significance of the ex-ante analysis of all premises for the occurrence of risk and the risk itself in the activities of a company implementing a project with the participation of European Union (EU) funds for the success of such an investment. The significance is so high, that before starting the investment process itself, it is necessary to anticipate and establish mechanisms preventing the occurrence or eliminating the effects of risk fulfillment at every stage of the process: planning, review, implementation monitoring and evaluation. The very awareness of decision-makers of the existence of various threats over time allows them to make decisions whether or not to undertake investments, even with access to non-refundable EU funding. The analysis was carried out on the basis of investment projects in the gas sector submitted for co-financing from the European Regional Development Fund under the Infrastructure and Environment Programme 2014-2020.

Key words: investments, risk, European Union funds, project management.

Autor do korespondencji: S. Kawa, e-mail: szymon.kawa@inig.pl

Artykuł nadesłano do Redakcji: 24.02.2021 r. Zatwierdzono do druku: 23.04.2021 r. 


\section{Wprowadzenie}

Infrastruktura energetyczna, a w szczególności gazowa, jest infrastrukturą kluczową z jednej strony z punktu widzenia rozwoju gospodarki ze względu na dostarczanie surowca wykorzystywanego do produkcji energii, z drugiej zaś - z punktu widzenia biznesowego, czyli opłacalności budowy tej infrastruktury. O ile nie można obecnie podważyć konieczności inwestowania w szeroko rozumianą energetykę, to już przedsiębiorstwo rozważające taką inwestycję musi przemyśleć, czy w ogóle jest ona wykonalna, biorąc pod uwagę uwarunkowania terenowe, środowiskowe, klimat społeczny, a także czy i na ile inwestycja taka zwróci się i przyniesie oczekiwane korzyści finansowe. Zatem decyzja o realizacji projektu inwestycyjnego jest podejmowana $\mathrm{w}$ zmiennych warunkach społecznych, ekonomicznych (szeroko rozumianych) i politycznych. Zmienność tych warunków, a dokładnie nieprzewidywalność przyszłych zdarzeń, prowadzi do niepewności co do skutków decyzji, które mają być podjęte na każdym etapie procesu inwestycyjnego. Najważniejsze jest wstępne ustalenie, czy można zaryzykować. To właśnie ryzyko determinuje podjęcie bądź zarzucenie projektu inwestycyjnego. Dlatego tak ważna jest analiza różnych czynników wpływających na sam proces inwestycyjny, jego otoczenie oraz spodziewane efekty. Dodatkowym aspektem skłaniającym do modyfikacji spojrzenia na ryzyka przedsięwzięcia inwestycyjnego jest ubieganie się oraz uzyskanie wsparcia finansowego z funduszy UE. Ten czynnik generuje bowiem dodatkowe ryzyka bezpośrednio i pośrednio związane z projektem.

\section{Miejsce ryzyka w zarządzaniu projektem}

W literaturze proces zarządzania dzielony jest na cztery elementy: planowanie, organizowanie, kierowanie (motywowanie, przewodzenie) oraz kontrolę (Griffin, 1996). To najbardziej klasyczne ujęcie, które można spotkać w pracach Druckera (2009), Griffina (1996) czy Stonera et al. (2011), jest opisywane i rozwijane przez innych autorów w literaturze związanej z nauką zarządzania w odniesieniu do przedsiębiorstwa, zasobów ludzkich, finansów czy w końcu projektów. Najistotniejsze jest bowiem to, by proces zarządzania był sprawny i skuteczny (efektywny) (Drucker, 2009).

Sprawność, czyli mądre, celowe i optymalne wykorzystywanie zasobów, oraz skuteczność, czyli osiągnięcie celu w warunkach niepewności, nie są takie oczywiste. Okazuje się bowiem, że zmienność otoczenia - zarówno wewnętrznego, jak i zewnętrznego - przedsiębiorstwa generuje z pewnym prawdopodobieństwem możliwości wystąpienia zdarzeń bezpośrednio lub pośrednio wpływających na planowanie, realizację i eksploatację projektu inwestycyjnego. W sektorze energetyki ma to szczególne znaczenie, ponieważ energia jest dla państwa strategicznym zasobem dla rozwoju gospodarki. Zatem można stwierdzić, że wszelkie decyzje związane z zarządzaniem w każdym aspekcie (finansowym, organizacyjnym, projektowym itd.) i na każdym etapie są obarczone ryzykiem.

Konieczne jest zatem zdefiniowanie ryzyka w procesie inwestycyjnym w sposób, który odda stany niepewności występujące w cyklu życia całego projektu. Ryzyko więc, to „kombinacja prawdopodobieństwa wystapienia zdarzenia oraz jego skutków; ryzyko zawsze wiąże się ze zdarzeniem będącym przyczyną (zagrożenie) i z zespołem warunków, w jakich to zagrożenie się realizuje" (Słodczyk i Mąkosa, 2008).

Koncentrując się wyłącznie na zarządzaniu projektem inwestycyjnym, należy bliżej przyjrzeć się zarządzaniu ryzykiem. Dla precyzji zrozumienia tego zagadnienia trzeba przede wszystkim zdefiniować pojęcie projektu inwestycyjnego w rozumieniu inwestycji w infrastrukturę.

Na potrzeby rozważań projektem niech zatem będzie każdy zespół przedsięwzięć powiązanych ze sobą technicznie, organizacyjnie czy finansowo realizowany w określonym czasie, którego realizacja zmierza do osiągnięcia określonego celu. Celowo w tym przypadku użyte zostało sformułowanie „zespół przedsięwzięć”. Przedsięwzięcie zdefiniowano tu - zgodnie z art. 3 ust. 1 pkt 13 Ustawy z dnia 3 października 2008 r. o udostępnianiu informacji o środowisku i jego ochronie, udziale społeczeństwa w ochronie środowiska oraz o ocenach oddziaływania na środowisko - jako „zamierzenie budowlane lub inną ingerencję w środowisko polegającą na przekształceniu lub zmianie sposobu wykorzystania terenu, w tym również na wydobywaniu kopalin; przedsięwzięcia powiązane technologicznie kwalifikuje się jako jedno przedsięwzięcie, także jeżeli są one realizowane przez różne podmioty" (art. 3 ust. 1 pkt 13). Inwestycje w infrastrukturę energetyczną bywają bowiem tak rozległymi inwestycjami, że każde z przedsięwzięć mogłoby stanowić odrębny projekt lub jego część, która po realizacji mogłaby funkcjonować samodzielnie. Jednakże wszystkie przedsięwzięcia razem tworzą jedną, większą całość o określonym przeznaczeniu. Znakomitym przykładem jest projekt inwestycyjny budowy terminalu regazyfikacji gazu ziemnego w Świnoujściu. Mówiąc o projekcie, należy także wskazać, wspomniany już przy definiowaniu ryzyka, bardzo istotny atrybut - cykl życia projektu. W skład tego cyklu, opisywanego w literaturze przedmiotu, wchodzi pięć elementów:

1) planowanie - działania planistyczne i projektowe prowadzące do przygotowania inwestycji;

2) przegląd - sprawdzenie wykonalności realizacji projektu i opłacalności pod kątem biznesowym;

3) wdrażanie - realizacja - wykonanie inwestycji; 
4) monitorowanie - bieżąca obserwacja prawidłowości realizacji projektu i działania korygujące;

5) ewaluacja - ocena - sprawdzenie efektów w odniesieniu do założeń.

Biorąc zatem pod uwagę z jednej strony elementy procesu zarządzania, z drugiej zaś cykl życia projektu, można skonstruować matrycę obszarów, w których będzie się identyfikować ryzyka danej inwestycji. Można również znaleźć prostą zależność, że im większa jest inwestycja, tym większe ryzyko braku sukcesu jej realizacji. Jest to jednak przedmiot odrębnych rozważań.

Matryca identyfikacji ryzyk (rys. 1) pokazuje, że w sposób zorganizowany zarządza się każdym etapem cyklu życia projektu, a co za tym idzie - można identyfikować ryzyko i odpowiednio na nie reagować.

\begin{tabular}{|c|c|c|c|c|c|c|}
\hline \multirow{4}{*}{ 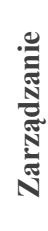 } & kontrola & & & & & \\
\hline & kierowanie & & & & & \\
\hline & organizowanie & & & & & \\
\hline & planowanie & & & & & \\
\hline & & 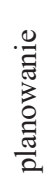 & 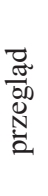 & 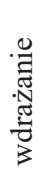 & 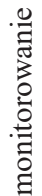 & $\frac{\frac{\pi}{0}}{\frac{\pi}{\Xi}}$ \\
\hline & & & & ia $\mathrm{p}$ & & \\
\hline
\end{tabular}

Rys. 1. Elementy identyfikowania ryzyk (źródło: opracowanie własne)

Fig. 1. Elements of risk identification (source: author's compilation)

Ze względu na to, że założeniem artykułu jest analiza projektów związanych z działalnością inwestycyjną/budowlaną, na tak skonstruowaną macierz należy nałożyć jeszcze jeden wymiar, w którym występują takie czynności jak:

- administracyjnoprawne;

- cywilnoprawne;

- faktyczne;

pomiędzy którymi zachodzą związki czasowe, przyczynowe oraz prawne. Są to decyzje i czynności podejmowane na przestrzeni całego okresu realizacji i eksploatacji projektu. Stąd powstają pola szczególnie wrażliwe na błędy oraz nieprzewidziane zdarzenia, mogące w sposób istotny wpłynąć na skuteczną realizację projektu inwestycyjnego.

\section{Podejście do ryzyka, teoria i praktyka}

W procesie realizacji projektu inwestycyjnego ryzyka powinny być znane kierownictwu na tyle, aby mogło ono podej- mować odpowiednie i odpowiedzialne decyzje. Dlatego też konieczna jest identyfikacja i analiza zagrożeń dla projektu na każdym etapie jego cyklu życia. Na rysunku 2 zaprezentowano ideowy schemat procesu inwestycyjnego/budowlanego wraz z miejscami identyfikacji ryzyk.

Są to zasadnicze momenty przy podejmowaniu decyzji. Już samo zatwierdzenie planu do realizacji wymaga, aby kierownictwo zapoznało się z wszelkimi warunkami, które przemawiają za i przeciw przystąpieniu do projektu. Zatem wstępne analizy i plany biznesowe powinny być na tyle atrakcyjne, aby nie budzić większych obaw decydentów. Na tym etapie pod uwagę bierze się zasadniczo aspekty opłacalności inwestycji - popytu i prognozowanych przychodów. Również uwarunkowania ekonomiczne (przewidywany kryzys), polityczne (regulacje prawne uniemożliwiające realizację projektu) i społeczne (możliwe protesty) mogą odegrać istotną rolę w procesie decyzyjnym.

$\mathrm{Na}$ etapie przeglądu projektu materiałem wyjściowym jest sporządzenie studium wykonalności. To ten dokument, choć bardzo obszerny, pokaże uwarunkowania inwestycji na podstawie analizy wszelkich czynników - począwszy od analizy prawnej, poprzez środowiskową, ekonomiczną i społeczną, na finansowej skończywszy. Tu właśnie zostanie określony budżet oraz montaż finansowy, czyli świadomy i celowy proces polegający na zidentyfikowaniu i wyborze instytucji finansowych uczestniczących w finansowaniu projektu inwestycyjnego oraz na określeniu proporcji środków pochodzących z różnych źródeł finansowania (Wojewnik-Filipkowska, 2008). Zatem na podstawie studium wykonalności możliwe jest zidentyfikowanie ryzyk, jakie mogą w przyszłości wystąpić zarówno na etapie wdrażania, jak też na etapie eksploatacji. To właśnie na podstawie tego opracowania analityczno-prognostycznego podejmuje się ryzyko realizacji projektu bez gwarancji jego powodzenia. Na tym etapie jedynym mechanizmem reakcji na ryzyko są analizy ekonomiczne i finansowe, które wskazują, jak duże jest ryzyko i czy można je podjąć z uwagi na korzyści w dłuższej perspektywie. Samym ryzykiem natomiast mogą być w tym momencie błędne decyzje wynikające z niewłaściwej interpretacji wniosków, zarówno dotyczących technologii, jak i ekonomiki wykonania inwestycji, co może się przełożyć bezpośrednio na fazę realizacyjną i eksploatacyjną.

Etap wdrażania to przygotowanie dokumentacji technicznej i realizacja projektu, czyli podjęcie decyzji o przyjęciu dokumentacji projektowych i budowlanych oraz wszczęcie procesu budowlanego. Jest to o tyle istotny etap, że w tym miejscu inwestor musi liczyć się z koniecznością zabezpieczenia 


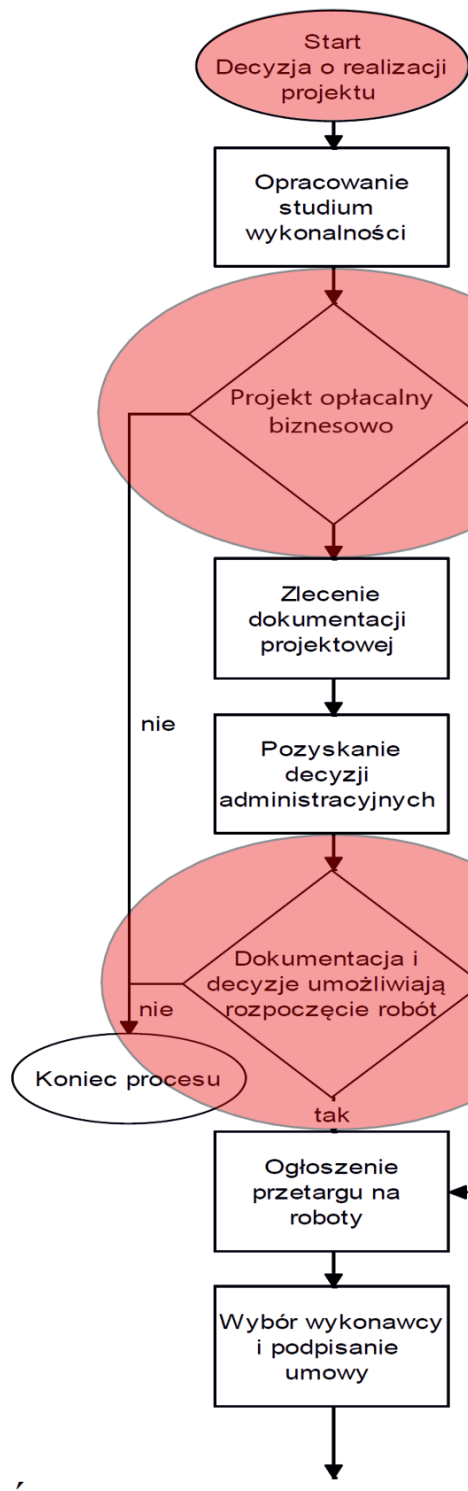

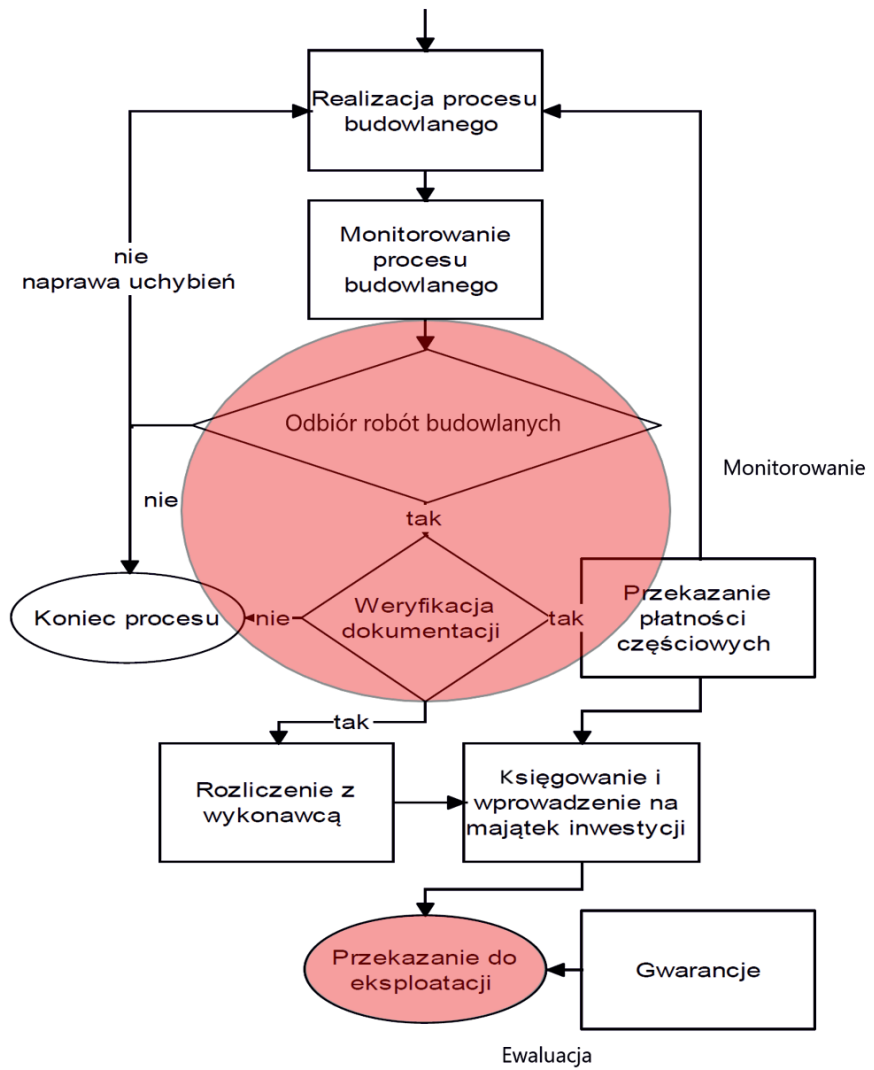

Rys. 2. Proces inwestycyjny - schemat ideowy (źródło: opracowanie własne)

Fig. 2. The investment process - an aggregate diagram (source: author's compilation) odpowiednich środków na przeprowadzenie procesu budowlanego. Za pozytywną decyzją idą kolejne elementy procesu, takie jak ogłoszenie przetargu ${ }^{1}$, wybór wykonawcy, a następnie monitorowanie prac. Ryzyka inwestora to przede wszystkim zachowanie płynności finansowej projektu, czyli zabezpieczenie środków na zaspokojenie zobowiązań wobec wykonawców. Ale to również odpowiedzialność za prawidłowe przygotowanie dokumentacji, zgodnie z którą wykonawcy będą realizować roboty budowlane. Zatem w procesie inwestycyjnym oprócz inwestora udział biorą także inne podmioty - przede wszystkim wykonawcy robót, jak również inspektor nadzoru budowlanego czy w przypadku projektów

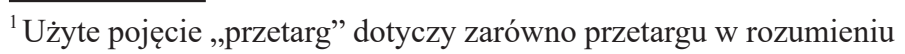
ustawy Prawo zamówień publicznych, jak też procedury wyłaniania wykonawcy w trybie art. $70^{1}-70^{5}$ Kodeksu cywilnego czy innych procedur wynikających z wewnętrznych uregulowań inwestora.
}

dużych - inżynier kontraktu, zarządzający budową w imieniu inwestora i na jego zlecenie ${ }^{2}$. Taka konieczność współpracy jest generatorem różnych ryzyk, bowiem ryzyka partnerów (np. wypłacalność, posiadane kompetencje) przekładają się na powodzenie realizacji projektu (tu duże znaczenie ma charakter zawartej umowy i podział ryzyk pomiędzy inwestora i wykonawcę).

Etap monitorowania projektu jest na bieżąco realizowany poprzez odbiory częściowe robót, ich kontrolowanie i w efekcie rozliczanie. To na tym etapie inwestor powinien dostrzegać ryzyka, w szczególności dotyczące terminowości realizacji, ale także zapewnienia odpowiedniej jakości wykonanych prac i użytych materiałów.

\footnotetext{
${ }^{2} \mathrm{~Np}$. zgodnie z międzynarodowymi standardami prowadzenia inwestycji - FIDIC - wymagane jest powołanie inżyniera kontraktu jako instytucji niezwiązanej z inwestorem.
} 
Bezpośrednio z monitorowaniem wiąże się ewaluacja, czyli ocena, czy projekt spełnił oczekiwania. Najpierw dokonywana jest ocena jakości projektu jako zrealizowanej całości. Jest to przesłanka do podjęcia decyzji o ostatecznym rozliczeniu inwestycji, czyli przyjęciu odbioru robót i zleceniu ostatnich płatności, łącznie ze zwolnieniem kwot zatrzymanych czy gwarancji, które są dużym obciążeniem dla inwestora i jego służb. Zasadniczo największym ryzykiem identyfikowanym na tym etapie jest brak możliwości przekazania projektu do eksploatacji, a co za tym idzie - brak możliwości odzyskiwania zainwestowanego kapitału z działalności operacyjnej. Przesłanki prowadzące do materializacji takiego ryzyka mogą mieć różny charakter: administracyjny (np. zmiany dokonane w trakcie realizacji projektu nie zostały formalnie przeprowadzone), prawny (np. spory utrudniające przekazanie do eksploatacji), społeczny (nierozwiązane konflikty społeczne) czy polityczny.

Nawet jeżeli inwestycja zostanie odebrana z powodzeniem i uruchomiona zostanie działalność operacyjna, pozostaje sfera niepewności co do efektywności ekonomicznej projektu w dłuższej perspektywie. Do głosu dochodzą bowiem czynniki związane z sytuacją finansową i pozycją konkurencyjną danego przedsiębiorstwa (inwestora), głównie popyt na produkty i usługi. Dopiero w tym momencie może się okazać, czy projekt zakończył się sukcesem.

Specyficznym aspektem w analizie ryzyka jest uzyskanie przez inwestora dofinansowania z funduszy europejskich (UE). Specyfika ta polega na tym, że olbrzymiemu wsparciu finansowemu dla projektu, bez którego to wsparcia realizacja inwestycji trwałaby znacznie dłużej, o ile w ogóle by do niej doszło, należy przeciwstawić nowe ryzyka pośrednio odnoszące się do projektu, a związane z wydatkowaniem funduszy europejskich. Zasadniczo w sektorze energetyki dofinansowanie udzielane jest na realizację inwestycji, stąd o ryzykach w tym aspekcie można mówić od etapu wdrażania projektu. Projekt może zostać dofinansowany, czyli przedsiębiorstwo powinno zaangażować w pewnym stopniu także kapitał własny (często również dłużny). W związku z tym ryzyka, jakie są związane z dotacjami, mają wymiar finansowy i są to: brak uzyskania dofinansowania oraz konieczność zwrotu całości lub części dofinansowania.

Pierwsze z wymienionych ryzyk jest mniej obciążające, ponieważ przedsiębiorstwo ryzykuje jedynie kapitałem własnym zaangażowanym w przygotowanie inwestycji. Często ten zaangażowany kapitał w późniejszym okresie zostanie wykorzystany, co sprawia, że skutki urzeczywistnienia się takiego ryzyka nie będą bardzo uciążliwe. Natomiast konieczność zwrotu może mieć bolesne konsekwencje. Przesłankami dla zwrotu dofinansowania są generalnie: niedotrzymywanie zasad określonych w odpowiednich przepisach i warunkach donatora lub brak osiągnięcia założonego celu (przy czym wynikać to może z przyjęcia pewnych założeń wyłącznie w celu uzyskania dotacji). W tym przypadku ryzykuje się nie tylko wartością dofinansowania, ale także kapitałem własnym, który powinien pokryć wysokość odsetek od stwierdzonej nieprawidłowości.

Czy zatem przedsiębiorstwa mają świadomość istnienia ryzyk związanych zarówno z projektem inwestycyjnym, jak i jego dofinansowaniem?

Opracowując zasady wdrażania funduszy europejskich Komisja Europejska, jako donator, określiła wzór wniosku o dofinansowanie dla dużych projektów ${ }^{3}$, który został przyjęty jako obowiązujący w sektorze energetyki. Przy składaniu wniosków o dofinansowanie wymaga się od przedsiębiorstw między innymi informacji na temat ryzyk związanych z realizacją projektu w dwóch aspektach (Rozporządzenie wykonawcze Komisji (UE) 2015/207):

- oceny ryzyka i analizy wrażliwości wykonanej w ramach analizy ekonomiczno-finansowej - należy przedstawić krótkie podsumowanie oceny ryzyka, w tym wykaz różnych rodzajów ryzyka, jakie mogą wystąpić w trakcie projektu, matrycę ryzyka, interpretację i proponowaną strategię ograniczania ryzyka oraz podmiot odpowiedzialny za ograniczanie głównych rodzajów ryzyka, takich jak przekroczenie kosztów, opóźnienia w czasie, spadek popytu; szczególną uwagę należy zwrócić na zagrożenia dla środowiska, rodzaje ryzyka związane ze zmianą klimatu oraz inne rodzaje ryzyka związane z klęskami żywiołowymi;

- opisu zagrożeń dla realizacji projektu - należy przedstawić krótkie podsumowanie głównych zagrożeń dla pomyślnej rzeczowej i finansowej realizacji projektu i proponowane środki zmniejszające ryzyko.

Informacje te nie mają jednak wpływu na podjęcie decyzji o udzieleniu dofinansowania, a wskazują instytucji podejmującej tę decyzję na świadomość istniejących zagrożeń, co może w przyszłości mieć wpływ na ocenę prawidłowości wykorzystania dofinansowania.

W poniższym zestawieniu zaprezentowano najczęściej pojawiające się ryzyka i metody ich ograniczania opisywane przez przedsiębiorstwa w projektach, które otrzymały wsparcie (tab. 1).

${ }^{3}$ Duży projekt w sektorze energetyki to projekt, którego wartość kosztów kwalifikowalnych (stanowiących podstawę dofinansowania) wynosi 75 mln euro (art. 100 Rozporządzenia Rady i Parlamentu Europejskiego nr 1303/2013 z dnia 17 grudnia 2013 r. ustanawiającego wspólne przepisy dotyczące Europejskiego Funduszu Rozwoju Regionalnego, Europejskiego Funduszu Społecznego, Funduszu Spójności, Europejskiego Funduszu Rolnego na rzecz Rozwoju Obszarów Wiejskich oraz Europejskiego Funduszu Morskiego i Rybackiego oraz ustanawiającego przepisy ogólne dotyczące Europejskiego Funduszu Rozwoju Regionalnego, Europejskiego Funduszu Społecznego, Funduszu Spójności i Europejskiego Funduszu Morskiego i Rybackiego oraz uchylającego rozporządzenie Rady (WE) nr 1083/2006. 
Tabela 1. Opis najczęściej identyfikowanych ryzyk w projektach UE

Table 1. Description of the most frequently identified risks in EU projects

\begin{tabular}{|c|c|c|}
\hline Ryzyko & Opis ryzyka i skutki & Postępowanie z ryzykiem \\
\hline $\begin{array}{l}\text { Zagrożenie } \\
\text { terminowej } \\
\text { realizacji projektu }\end{array}$ & $\begin{array}{l}\text { 1. Wzrost cen usług i dostaw warunkujący konieczność pozyska- } \\
\text { nia dodatkowych środków finansowych. } \\
\text { 2. Błędy po stronie wykonawcy usług, niedotrzymanie terminów } \\
\text { przewidzianych w harmonogramie projektu, problemy techno- } \\
\text { logiczne wynikające z poziomu innowacyjności projektu. } \\
\text { Skutki: } \\
\text { - konieczność aneksowania umowy o dofinansowanie; } \\
\text { - problemy z rozliczeniem i pozyskaniem dotacji; } \\
\text { - zwiększenie nakładów w okresie realizacji prac; } \\
\text { - konieczność pozyskania dodatkowych środków w zakresie fi- } \\
\text { nansowania wkładu własnego. }\end{array}$ & $\begin{array}{l}\text { Posiadanie odpowiednich procedur wyboru wyko- } \\
\text { nawców. } \\
\text { Klauzule umowne dotyczące kar umownych za } \\
\text { opóźnienie w realizacji (przeniesienie ryzyka na } \\
\text { wykonawcę). } \\
\text { Wysoka dynamika realizacji projektu - wypraco- } \\
\text { wanie rezerw czasowych, rozszerzenie zespołów } \\
\text { realizujących poszczególne działania (minimaliza- } \\
\text { cja ryzyka). } \\
\text { Aktywne zarządzanie harmonogramem projek- } \\
\text { tu, wczesna identyfikacja zdarzeń mogących mieć } \\
\text { wpływ na terminowość wdrożenia projektu. } \\
\text { Powołanie odpowiedniej struktury organizacyjnej } \\
\text { odpowiedzialnej za komunikację pomiędzy zespo- } \\
\text { łami realizującymi projekt. }\end{array}$ \\
\hline $\begin{array}{l}\text { Wzrost nakładów } \\
\text { inwestycyjnych }\end{array}$ & $\begin{array}{l}\text { Przekroczenie kosztów inwestycyjnych wynikające głównie z moż- } \\
\text { liwości wzrostu cen dostaw i usług. } \\
\text { Skutki: } \\
\text { - konieczność aneksowania umowy o dofinansowanie; } \\
\text { - konieczność pozyskania dodatkowych środków w zakresie fi- } \\
\quad \text { nansowania wkładu własnego. }\end{array}$ & $\begin{array}{l}\text { Szczegółowa analiza kosztów inwestycji. } \\
\text { Przeniesienie części ryzyka wzrostu cen na wyko- } \\
\text { nawcę - zastosowanie metody rozliczania kwotą } \\
\text { ryczałtową. }\end{array}$ \\
\hline $\begin{array}{l}\text { Procedury } \\
\text { wyboru i wybór } \\
\text { wykonawców }\end{array}$ & $\begin{array}{l}\text { 1. Interpretowalność przepisów prawa i regulacji - błędy proce- } \\
\text { duralne. } \\
\text { 2. Przygotowanie dokumentacji przetargowej niezgodnej z prze- } \\
\text { pisami prawa. } \\
\text { 3. Odwołania oferentów w procedurach przetargowych. } \\
\text { 4. Utrata korzyści w związku z opóźnieniami w realizacji harmo- } \\
\text { nogramu projektu. } \\
\text { Skutki: } \\
\text { - niedotrzymanie terminów realizacji prac; } \\
\text { - zwiększenie nakładów w okresie realizacji prac; } \\
\text { - zmiana wykonawców w okresie realizacji; } \\
\text { - konieczność aneksowania umowy o dofinansowanie; } \\
\text { - konieczność pozyskania dodatkowych środków w zakresie fi- } \\
\text { nansowania wkładu własnego. }\end{array}$ & $\begin{array}{l}\text { Monitorowanie zmiany w przepisach prawa. } \\
\text { Weryfikacja wewnętrzna dokumentacji przetargo- } \\
\text { wych z doradcami i prawnikami oraz uwzględnie- } \\
\text { nie zaleceń ze strony Urzędu Zamówień Publicz- } \\
\text { nych również z innych projektów. } \\
\text { Uzgodnienia wszystkich wymagań wobec inwesty- } \\
\text { cji (środowisko, jakość materiałów i urządzeń itp.). }\end{array}$ \\
\hline $\begin{array}{l}\text { Problemy } \\
\text { z uruchomieniem } \\
\text { i wdrożeniem } \\
\text { projektu do } \\
\text { eksploatacji }\end{array}$ & $\begin{array}{l}\text { 1. Zmiany w prawie i regulacjach w czasie wdrożenia. } \\
\text { 2. Przechwycenie danych wrażliwych przez nieuprawnione pod- } \\
\text { mioty. } \\
\text { 3. Wzrost cen urządzeń niezbędnych do realizacji inwestycji oraz } \\
\text { zmiany kursów walutowych. } \\
\text { 4. Opóźnienia w realizacji projektu względem harmonogramu. } \\
\text { 5. Zdarzenia trudne do przewidzenia, w tym spowodowane gwał- } \\
\text { townymi zmianami meteorologicznymi lub klęskami żywioło- } \\
\text { wymi. } \\
\text { 6. Problemy techniczne wynikające z wdrożenia, w tym brak } \\
\text { zgodności sprzętu i oprogramowania, awaryjność elementów } \\
\text { infrastruktury i brak kompatybilności urządzeń. } \\
\text { Skutki: } \\
\text { - zagrożenie w osiągnięciu zakładanych efektów; } \\
\text { - problemy z rozliczeniem płatności końcowej; } \\
\text { - wydłużenie terminu zakończenia prac; } \\
\text { - konieczność aneksowania umowy o dofinansowanie. }\end{array}$ & $\begin{array}{l}\text { Monitorowanie zmiany w przepisach prawa i pro- } \\
\text { cesach legislacyjnych. } \\
\text { Przestrzeganie procedur bezpieczeństwa informacji } \\
\text { oraz zobowiązanie wykonawców do ich przestrze- } \\
\text { gania poprzez odpowiednie zapisy w umowach. } \\
\text { Dokładne opracowanie zakresu inwestycji, re- } \\
\text { alnego harmonogramu oraz planu finansowania } \\
\text { uwzględniającego możliwość wystąpienia zdarzeń } \\
\text { nieprzewidywalnych. } \\
\text { Bieżące monitorowanie harmonogramu i realizacji } \\
\text { planu finansowania, odpowiednie korygowanie roz- } \\
\text { bieżności. } \\
\text { Wybór wykonawców z odpowiednimi kompeten- } \\
\text { cjami i doświadczeniem. } \\
\text { Klauzule umowne zabezpieczające przedsiębior- } \\
\text { stwo w przypadku niskiej jakości usług. } \\
\text { Opracowanie szczegółowego projektu wykonaw- } \\
\text { czego określającego wszystkie warunki realizacji. } \\
\text { Systematyczna kontrola wykonawstwa. }\end{array}$ \\
\hline
\end{tabular}


cd. Tabela $1 /$ cont. Table 1

\begin{tabular}{|c|c|c|}
\hline Ryzyko & Opis ryzyka i skutki & Postępowanie z ryzykiem \\
\hline $\begin{array}{l}\text { Ryzyko } \\
\text { eksploatacyjne }\end{array}$ & $\begin{array}{l}\text { 1. Przekroczenia budżetu lub niewystarczające finansowanie. } \\
\text { 2. Problemy techniczne (jakość transmisji danych, awaryjność } \\
\text { elementów infrastruktury, brak kompatybilności nowych urzą- } \\
\text { dzeń). } \\
\text { Skutki: } \\
\text { - problemy z osiągnięciem i utrzymaniem zakładanych efektów; } \\
\text { - konieczność zwracania części dotacji; } \\
\text { - konieczność ponoszenia dodatkowych wydatków związanych } \\
\text { z eliminacją czynnika ryzyka. }\end{array}$ & $\begin{array}{l}\text { Monitorowanie postępu prac i pojawiania się no- } \\
\text { wych kosztów wdrożenia zagrażających budżeto- } \\
\text { wi projektu. } \\
\text { Wdrożenie standardów akceptowania wydatków } \\
\text { i dokładne szacunki kosztów w trakcie przygoto- } \\
\text { wywania koncepcji wdrożenia. } \\
\text { Wybór wykonawców z odpowiednimi kompeten- } \\
\text { cjami i doświadczeniem. } \\
\text { Bieżący przegląd istniejącej infrastruktury i elimi- } \\
\text { nowanie elementów, które mogą powodować uster- } \\
\text { ki w nowych urządzeniach. } \\
\text { Zapewnienie nadzoru technicznego. }\end{array}$ \\
\hline $\begin{array}{l}\text { Ryzyko wpływu } \\
\text { na środowisko } \\
\text { i klimat }\end{array}$ & $\begin{array}{l}\text { Zagrożenia dla środowiska } \\
\text { 1. Źródło zanieczyszczeń takich jak emisja pyłów lub/i gazów, po- } \\
\text { wstawanie ścieków lub innych odpadów w procesie realizacji. } \\
\text { 2. Emisja zanieczyszczeń przez urządzenia, które będą wykorzy- } \\
\text { stane w projekcie - w okresie eksploatacji. } \\
\text { 3. Wpływ na występowanie zjawisk pogodowych. } \\
\text { Zagrożenia dla projektu: } \\
\text { Zmiany klimatu mogą prowadzić do występowania burz, intensyw- } \\
\text { nych opadów, znacznych wahań temperatur, ekstremalnych warun- } \\
\text { ków atmosferycznych. Powyższe powodować mogą uszkodzenia } \\
\text { infrastruktury. } \\
\text { W konsekwencji mogą wystąpić przerwy w dostawach energii oraz } \\
\text { niebezpieczeństwo dla ludzi i otoczenia. }\end{array}$ & $\begin{array}{l}\text { Określenie warunków w taki sposób, aby realizacja } \\
\text { inwestycji była jak najmniej uciążliwa dla klimatu } \\
\text { i środowiska. } \\
\text { Dzięki zastosowanym technologiom smart monito- } \\
\text { rowania pracy infrastruktury będzie możliwe opty- } \\
\text { malne jej wykorzystanie w zależności od potrzeb. } \\
\text { Zastosowanie nowoczesnych technologii eksploata- } \\
\text { cji, w tym inteligentnych funkcjonalności. }\end{array}$ \\
\hline
\end{tabular}

Źródło: Opracowanie własne na podstawie wniosków aplikacyjnych o dofinansowanie z Europejskiego Funduszu Rozwoju Regionalnego w ramach działania 7.1 Programu Operacyjnego Infrastruktura i Środowisko 2014-2020.

\section{Podsumowanie}

Ryzyko w projektach inwestycyjnych jest zatem obszarem wymagającym jeszcze gruntownej eksploracji. Istnieją już systemy informatyczne pozwalające na oszacowanie i wycenę ryzyka, jednak istota problemu tkwi w jego identyfikacji, znalezieniu zagrożeń i określeniu ich wpływu na każdym etapie cyklu życia projektu w procesie zarządzania projektem. Na początku artykułu postawiono tezę, zgodnie z którą analiza ryzyka powinna pozwolić na zminimalizowanie, uniknięcie lub przeniesienie niektórych niekorzystnych czynników otoczenia projektu, tak aby zapewnić jak największą skuteczność jego realizacji. A to z kolei świadczyć będzie o dobrym zarządzaniu projektem. Z przeprowadzonej analizy wynika, że wymuszenie przez reguły funduszy europejskich przeanalizowania niekorzystnych uwarunkowań oraz zaproponowania odpowiednich reakcji czy rozwiązań korzystnie wpływa na proces aplikowania o dofinansowanie oraz realizację projektu. Występujące bowiem nieuniknione $w$ tak dużych inwestycjach błędy mogą być na tyle wcześnie identyfikowane, że możliwe będzie zminimalizowanie skutków finansowych dla inwestora. Z kolei zabezpieczenia przed innymi możliwymi zdarzeniami pozwalają unikać turbulencji przy realizacji harmonogramu i ewentualnie szybko reagować na pojawiające się problemy. Ma to swoje uzasadnienie w danych dostępnych w instytucjach nadzorujących wydatkowanie funduszy UE, również w Instytucie Nafty i Gazu - Państwowym Instytucie Badawczym, który nadzoruje realizację 57 projektów, z których 6 zostało zakończonych $\mathrm{w}$ terminie lub przy nieznacznym jego przekroczeniu przy wykorzystaniu całości przyznanej dotacji.

Niemniej zagadnienie wydaje się rozwojowe. Nakładając metody probabilistyczne na proces analizy ryzyka, można uzyskać dokładniejsze szacunki, w szczególności kosztów podjęcia lub zaniechania ryzyka inwestycyjnego, co przy pozostającej sferze niepewności czyni łatwiejszym podejmowanie określonych decyzji.

\section{Literatura}

Drucker P.F., 2009. Menedżer skuteczny. Wydawnictwo MT Biznes Sp. z o.o., Warszawa.

Griffin R.W., 1996. Podstawy zarządzania organizacjami. Wydawnictwo PWN, Warszawa.

Słodczyk A., Mąkosa P., 2008. Zarządzanie ryzykiem w działalności gospodarczej - część 1 dot. bezpieczeństwa informacji. Zabezpieczenia, 5: 37-39. 
Stoner J.A.F., Freeman R.E., Gilbert D.R., 2011. Kierowanie. Wyd. 2. Polskie Wydawnictwo Ekonomiczne, Warszawa.

Wojewnik-Filipkowska A., 2008. Project finance w inwestycjach infrastrukturalnych. CeDeWu, Warszawa.

\section{Akty prawne i dokumenty normatywne}

Rozporządzenie wykonawcze Komisji (UE) 2015/207 z dnia 20 stycznia 2015 r. ustanawiające szczegółowe zasady wykonania rozporządzenia Parlamentu Europejskiego i Rady (UE) nr 1303/2013 w odniesieniu do wzoru sprawozdania z postępów, formatu dokumentu służącego przekazywaniu informacji na temat dużych projektów, wzorów wspólnego planu działania, sprawozdań z wdrażania w ramach celu „Inwestycje na rzecz wzrostu i zatrudnienia”, deklaracji zarządczej, strategii audytu, opinii audytowej i rocznego sprawozdania z kontroli oraz metodyki przeprowadzania analizy kosztów i korzyści, a także zgodnie z rozporządzeniem Parlamentu Europejskiego i Rady (UE) nr 1299/2013 w odniesieniu do wzoru sprawozdań z wdrażania w ramach celu „Europejska współpraca terytorialna”.

Ustawa z dnia 3 października 2008 r. o udostępnianiu informacji o środowisku i jego ochronie, udziale społeczeństwa w ochronie środowiska oraz o ocenach oddziaływania na środowisko (Dz.U. z 2008 r. nr 199, poz. 1227 ze zm.).

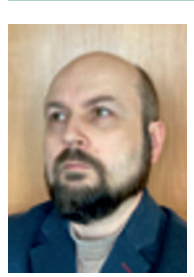

mgr Szymon KAWA

Starszy specjalista w Centrum Funduszy

Europejskich dla Energetyki

Instytut Nafty i Gazu - Państwowy Instytut Badawczy

ul. Lubicz $25 \mathrm{~A}$

31-503 Kraków

E-mail: szymon.kawa@inig.pl

\section{OFERTA BADAWCZA ZAKŁADU NAWANIANIA PALIW GAZOWYCH}

- kontrola analityczna procesu nawaniania gazu (w tym m.in. pomiary weryfikuiące stężenie środka nawaniającego $w$ gazie ziemnym i mieszaninach gazowych, kontrola pracy urządzeń nawaniaiących itp.);

- nadzór metrologiczny nad poprawnością wskazań analizatorów procesowych stężenia środka nawaniającego, działających w systemie on-line;

- kontrola stopnia nawonienia gazu, realizowana m.in.: poprzez pomiary kontrolne intensywności zapachu paliw gazowych, wyznaczanie minimalnego stężenia środka nawaniającego w gazie oraz weryfikację krzywych zapachowych paliw gazowych;

- wyznaczanie krzywych zapachowych gazów;

- badania jakości środków nawaniających;

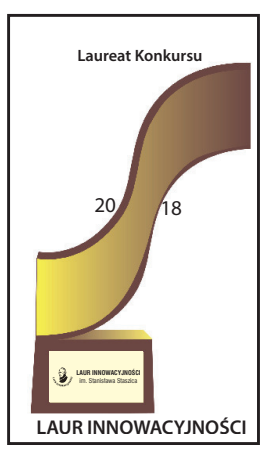

LAUR INNOWACYJNOŚCI

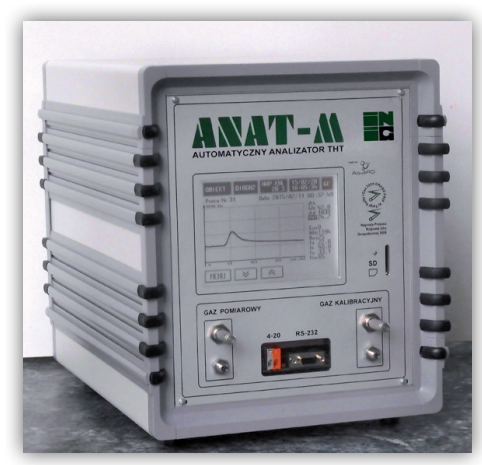

prace badawcze dotyczące wprowadzania nowych środków nawaniających do krajowego systemu gazowniczego oraz monitorowanie procesu;

- produkcja i serwisowanie automatycznych analizatorów chromatograficznych, przeznaczonych do pomiaru stężenia THT w gazie, typu ANAT-M;

sporządzanie mieszanin wzorcowych THT;

projektowanie nowoczesnych urządzeń do pomiaru stężenia środków nawaniających w gazie oraz jakosci zapachowej gazów.

Kierownik: dr Anna Huszał Adres: ul. Kasprzaka 25, 01-224 Warszawa 